\title{
Public Accountability and Parliamentary Scrutiny in Finance
}

\begin{abstract}
The purpose of parliament is to present a discussion of policy in a fashion that will bring about a consensus that results in collective action. Such a collective action serves the common good of the state, although second-order effects and Pareto optimality is difficult to obtain, if not impossible. Parliament attempts to address the second-best world in a socially optimal fashion. As such accountability and scrutiny are the key tools through which such a body can address the challenges faced by a financial sector faced with profound difficulties. Such accountability is of paramount importance to provide sustainable public trust in parliament.
\end{abstract}

Keywords: Public Accountability; Financial Crisis; Banking Crisis; Public Inquiry.

\section{Introduction}

The banking guarantee provided by the Irish government of 29 September 2008 constituted the highest net cost for a bank bailout globally at $22.3 \%$ of GDP between 2007 and 2010. 268.5\% of GDP was the gross cost of actual resources committed to save the banking system in Ireland. The result was stark. Ireland instantly deteriorated from a country with one of the lowest debt to GDP ratios to one of the highest (Connor et al. [2012]; Corbet and Twomey [2014]; Corbet [2016]; Whelan [2014]). The banking system became entirely reliant on ECB support to function and in November 2010 it was utilising almost a quarter of ECB resources within it budgetary system. Such interventions accounted for approximately $99 \%$ of Irish GDP at their height. Ireland entered into a multilateral official sector support programme, received from a group commonly denoted as the Troika (A group formed by the European Commission, the European Central Bank and the International Monetary Fund), on 10 December, 2010 (Corbet and Larkin [2017]; Hick [2018]; Lucey et al. [2014]). Economically and politically Ireland appeared to be no longer an independent nation as it began a period of pronounced austerity.

In the aftermath of this economic collapse, in an attempt to generate some form of public accountability, the Irish government announced the creation of a Banking Inquiry which was primarily identified as an attempt to address the key questions and attribution of criminal accountability for decision-making and behaviour both before and during the financial crisis. Such inquiries have become numerous since the end result was such an extensive economic collapse. The problem with a clear a priori was that the veracity of 
that initial position needs to be tested. For example, such inquiries must establish as to what prior assumptions must be established about the cause or causes of the crisis? Who was responsible for the crisis, bankers, officials, politician, the Eurocrats, the 'markets', the media or all of the above? Was it gross incompetence or corruption or a combination? Was it arrogance or ignorance? Was this a national humiliation or just a consequence of a decades-long policy of shifting decision making to different people without thought to the consequences? A large part of this analysis is trying to figure out, on a human scale, the direct line of causation from boom to crisis and from there to come up with remedies that are possible to be fashioned in law. The complication is this must all take place in a politically charged environment. This paper provides the perspective of the policymaker, that must navigate between the art of the possible and the genuine anger of a population that must understand as to what has happened and as to why their lives have been so acutely affected through little or no fault of their own.

\section{The Role of the Banking Inquiry}

The purpose of such an inquiry as that created in Ireland is to bring about a modicum of parliamentary scrutiny and oversight to the economic crash in Ireland in 2008. To achieve such a task, events that appeared to be beyond the control of those in economic and political power have been reduced to analytically useful sizes, if only to make them appear on a more human scale. The entire framework of the Inquiry was based on the provision of a legally-neutral, analytically accessible and socially-cognate approach to the discovery of evidence. The Inquiry created a framework for investigating the Irish economy: within the bank-property-state nexus. This approach is clearly in keeping with what could be seen in a lifetime as a public policy economist in Ireland. Regulatory capture, deeply entrenched interest groups, political business cycles, an acceptance of incompetence and a permanent government repugnant to reform. The interesting issues related to this nexus relates to how it went from something unpleasant and economically detrimental in the period of the 1970s onward into something economically devastating. We would argue that much of the blame lies not so much in the congenital issues but in the external environment adjacent to those congenital problems of the Irish political economy. The economy was undone by hot money inflows, untrammelled or regulated by a monetary union without a banking union and a series of cheerleaders on the side-lines including the professions, the Central Bank and the civil service and the media at large.

Some of the problems came from taking an oligopolistic banking sector and a political economy geared towards property and allowing it to behave as it would have if the country did have money (Connor et al. [2012]; Donovan and Murphy [2013]; Honohan [2009]; Honohan [2010]; Kinsella [2012]). Therein lies the congenital issue. Ireland's economic system had inbuilt weaknesses that could only become debilitating diseases when enabled by plentiful and cheap credit. Obviously the Inquiry had to come up with a policy solution to prevent that predisposition from returning as a problem. The more difficult matter is 
the deep regulatory capture as witnessed by the sins of omission committed by the Central Bank and the civil service. They were willing to be captured by interest groups, partly as a function of the political economy of Ireland but also due to a profound lack of expertise. That lack of expertise was in evidence going back to the early 1990s during the early stages of the EMU negotiations. The media also played a role. The media's reliance on property advertising revenue was similar to the Department of Finance's reliance on Stamp Duty and VAT receipts. If the property house of cards toppled then the entire edifice of the print media especial would be placed in jeopardy, just like the fiscal position of the State feel apart in the absence of all that stamp and VAT revenue. Internationally Ireland's 'Celtic Tiger' was pronounced as the 'new paradigm' for economic development and catch-up, a new economic Icarus in the making (Kirby [2016]).

The challenge of the bank-property-state nexus is that it goes to the very core of the Irish economic system and the political system. It is only right that the Inquiry focused on the reform of the Irish political economy given our existential crisis but will this committee have the time and the remit to grapple with the entrenched interest groups and challenge the regulatory capture that continues to be business as usual? We will attempt to answer this question by first looking at the design of the Inquiry and some of the pre-existing official reports.

\section{Insert Figure 1 about here}

Informing the Inquiry's outline is the idea that the political economy of Ireland at the close of the boom was fundamentally attached to facilitating an economy based upon property. The Banking Inquiry hoped to discover the reasons why the Celtic Tiger failed so dramatically and how the banking-property-state nexus resulted in the Guarantee, the Bailout and the protracted period of high unemployment, low growth and fiscal austerity we have experienced during the years of economic crisis. The less generous understanding of the Banking Inquiry is that it is a calculated programme of political theatre that attempted to attribute some form of political accountability for the collapse of the Irish economy. There is a strong desire to find and punish the person or persons responsible. This is understandable. While academics and technocrats enjoy bettering their intellectual and official opponents rarely does their continued employment depend upon such successes. Furthermore, there exists a problem, which Prof. Bill Black calls 'the Lord Voldemort rules, He-Who-MustNot-Be-Named...resulting in a most surreal experience' in which members of the inquiry and witnesses need to be extremely careful about who is named in the course of hearings due to ongoing and potential legal implications.

To provide a brief localised example, Section 42 of the Freedom of Information Bill 2013 exempts from freedom of information 'any of the supervisory directives within the meaning of the Central Bank Act 1942.' In rejecting an amendment to counteract this secrecy the Minister stated that this was a requirement of the European Central Bank. In this 
situation, the occlusion of the banking sector from external scrutiny is not only facilitated by an official body but required to be incorporated into the national body of law. Article 33AK of the Central Bank Act 1942 precludes any form of date, individual, firm or decision identifiable notes to be produced from the materials provided the Central Bank of Ireland to the Inquiry. We may speak of the Central Bank but in hushed tones and not too much detail, as if the practices of the organisation were akin to the inner sanctum of the Temple of Jupiter.

It is important to pause here to see the implications. The push to drive things to a human scale creates the possibility of human responses. Recriminations and accusations are easily offered as analysis. Here say evidence is accepted as truth. Certain histories, born of memories of crisis meetings in the small hours of the morning, are given profound credulity by an audience that has come to expect a certain story. The story of evidence is the story of how law evolved from custom and practice to legal science. Parliaments have been the losers in this evolution for the most part. While few desire a return to the Star Chamber of Henry VIII or the right for an Earl to be judged by 'God and my Peers', parliament's powers to draw evidence towards itself and ensure its veracity has been thrown in high relief in this process. The surreal nature of statements that Prof. Black describes places matters of parliamentary privilege and the separation of powers concept into question. If the judiciary fears a parliament and a parliament fears a judiciary and both can ensure that the transaction cost for the slightest infraction will ensure the most deep-seated risk aversion dominates all public and private interactions by persons will there be such a thing as evidence or merely carefully crafted artifices that comply with the rules of engagement. The whole concept of scrutiny and oversight falls apart under such conditions. Parliament become theatre. Policy becomes a product of artifice and not analysis.

Politics makes the process of analysis difficult since the Baconian norms that we as academics take for granted do not apply. Politics is different. The members are always conscious of the return on investment for every minute they listen to a senior civil servant or banker they are away from their constituency office or progressing a citizen's grievance against some aspect of officialdom. Political points scored against opposing parties or figures of public opprobrium can result in needed media coverage to remind people of their representative and that they are doing something they vaguely agree with (or more importantly, don't disagree with). The risk is that such events devolve into partisan circuses, creating much heat but little light. Due to very strict rules outlined in legislation such problems have been largely eliminated. At the same time alternative problems can be generated, where everyone is far too polite. This has already been an accusation against the Irish inquiry that participants are allowed to enter a public confessional, a national truth and reconciliation commission that imparts no blame following a televised mea culpa. 


\section{Politics, policy and financial crisis}

Politics and sophisticated policy in the wake of the crisis have become strange bedfellows. Votes rarely are garnered for the eloquence of a committee report or the inclusion of a crucial paragraph in the BRR directive. While many see that as a flaw of the political system, it is a reality and in the absence of an alternative it must be understood as part of the transactions costs of residing in a Western constitutional democracy. A mental frailty that politicians, technocrats and generals all suffer from is a desire to re-run the last war with beautiful precision and design. As the picture of what happened in Ireland from 1992 to 2008 becomes clearer, the immediate changes introduced between 2009 and now close many stable doors. It is a concern that parliamentary investigations only discourage bold policymaking, finding solace in studying Thermopylae while awaiting the Somme, the past may be known and safe but it is the risky and uncertain known and unknown present and future that policymakers must engage.

Some of this can be considered to be a function of policy-cyclicality, something that the Bank of England is acutely aware of as it attempted to telescope the decades and centuries to learn more about preventing policy failures. This was something that was not entirely present in the US Dodd-Frank Act (2010) that addressed the past and added complexity. While the sophistry of some legal and financial engineering may escape most of the population, the broad strokes of policy solutions are clearly understood by those who are willing to be moderately informed about the business of government. This has generated political responses which are important to note and address. The parliamentary process has not yet created enough change in culture, power distribution or equitable remedy. At present our esteemed colleagues of the legal profession have forged new and interesting approaches to the crisis. These startle economists and terrify financiers, such as the newly proposed German Abwicklungsmechanismusgesetz to implement the Single Resolution Mechanism (Coleman et al. [2018]). The response has been different forms of populism in different contexts (Corbet and Larkin [2018]). In the US the rise of Sen. Elizabeth Warren was a response to the failures of the Dodd-Frank Act and the partisan bickering that accompanied the publication of the Financial Crisis Investigation Committee report in 2011 (including the Peter Wallison externally published dissent). In the European context the rise of figures such as Finance Minister Yanis Varoufakis illustratd an environment where the traditional post-war political consensus is becoming threadbare. While this is not the focus of this paper, it is something that all parliamentarians have become conscious of since the financial crisis. Results in Spain, Greece, France and in the European Parliament highlighted that the bedrock of the European project, most clearly outlined in grand consensus EPP party, illustrate that 'business as usual' is under concerted attack.

In terms of providing scrutiny and oversight, the result is sub-optimal. A political and policy environment is created in which a cacophony of views eventually coalesce around demagoguery, and more worrying well-intentioned demagoguery, the type that ostracised Themistocles at the height of the Peloponnesian Wars. We use this analogy advisedly 
in the context of the US legislative proposals (Warren-Vitter) that will have profound implications for the future of the lender of last resort power of the Federal Reserve. This is the result of pursuing a modern-day Cincinnatus, a forceful leader that will farm their fields after the crisis but the public discovers only a Coriolanus or weak-willed Tribunes returned after snap elections. While the politics descends into a quagmire of personal advantage versus public benefit the state of the banking systems of Europe continues to cause concern (Becker and Ivashina [2017]; Black et al. [2016]; De Marco [2019]; Nugent [2017]). While micro and macroprudential regulations have been put in place, Ireland's banking system is still very fragile (Cooper and Nikolov [2018]). Despite this Ireland's banking system now accounting for continued losses as non-performing loans remain high compared to international averages, and for major questions to be asked of the two Pillar Banks with respect to their customer practices. While the Minister of Finance seeks to dispose of AIB, it still remains an aberration to the taxpayer, with $99 \%$ ownership by the State.

There are two schools of thought on such investigations. Some feel that they should be conducted while the crisis is still fresh, like the US Congressional investigation in 2009/10. Others would feel that more time should exist between the event and the analysis. The Pecora Commission highlights the benefit of this approach, in that his review of the actions that resulted in the Wall Street 1929 crash and subsequent rash of bank failures was much more powerful than earlier investigations. It is because of this distance that the 1933 Banking Act was much more stringent than the earlier version of Glass-Steagall. If we wait until the battlefield has been entirely cleared, do we get to a stage where people have moved on and see this as a waste of public money? What are the implications of discussing events which are essentially ongoing? The events of the Guarantee are still raw and the obsession from the public and media betrays a lingering trauma, as if the shock of what happened to the nation has just set in. The depth of the crisis in Ireland, much like that in many other smaller countries across the EU, appears to cast a much longer shadow than in the US, UK or core Eurozone countries.

We must further consider the specific responses in a European context throughout political constructs including commissions of investigation and further expert inquiries. Contemporary democracies have long-established constitutional and criminal procedures through which they attempt to create cultures designed to opposed corruption. All of which are also designed to also account for wrong-doing by political and administrative officials, so as generate accountability. Greece's democratic regime was also equipped with such accountability mechanisms, however, many feared that they may not have been robust enough to properly challenge wrong-doing. In Greece, an Ombudsman of investigation had been established in 1997 and was largely entrusted to function as an intermediary between the Greek population and the public administration, managing complaints, but possessing little enforcement power. A General Inspector of Public Administration was developed on this layer in 2002, while the Financial and Economic Crime Unit (SDOE), established in 2007, was developed to oppose economic criminality within the country, further supported by 
the Internal Affairs Unit of the Greek Police is charged with investigating cases of corruption across government ministries and state agencies. These individual units were largely accountable for the investigation and presentation of the core issues central to the Greek financial crisis in the period after the rapid expansion of crisis after 2008. These agencies were further supported by politically-driven inquiries that were established by the SyrizaANEL Coalition government, where the Speaker of the Parliament Zoe Constantopoulou presided over a fact-finding truth commission. The commission, consisting of 30 Syriza and ANEL MPs and Greek and international experts was assigned to draft a report after carrying out an audit of the Greek public debt. Very similar mechanisms were also established in Iceland and Cyprus, where largely politically-driven accountability was sought.

The crisis also influenced the structure in which the ECB sought accountability. First, the crisis affected all major central banks and the scrutiny of monetary policy became more complicated owing to the exceptional economic circumstances and the recourse to non-standard measures. The second uniquely affected the ECB, as it stemmed from the evolution of the institutional framework of Economic and Monetary Union (EMU) in response to the crisis. The ECB was given responsibility for the microprudential supervision of the euro area banking system with the creation of the Single Supervisory Mechanism (SSM) in 2014. With the entry into force of the SSM Regulation, the ECB was also given macroprudential tools to tackle the emergence of possible systemic risks in the financial system. Therefore, three 'traditional' channels of the ECB accountability framework have been extended to ECB Banking Supervision. Firstly, the Chair of the Supervisory Board attends regular hearings and exchanges of views in the European Parliament. Second, MEPs can address written questions related to supervision to the Chair of the Supervisory Board. Finally, since 2014 the ECB has published an annual report on its supervisory activities, which is presented by the Chair of the Supervisory Board to the European Parliament at a public hearing. The report is also submitted to the Council, the Eurogroup, the Commission and the national parliaments of participating Member States.

\section{Central Banking: Theory and Reality}

The exchange of letters between then ECB president Trichet and the late Minister for Finance Brian Lenihan made clear that Ireland was being forced into an official sector bailout. The ECB legally exists above national parliaments and is not accountable to them or to the Council of Ministers (Barrett [2018]; Tesche [2018]). As such it would not directly cooperate with the Oireachtas Banking Inquiry, it would only address the European Parliament and largely on non-specifics. A compromise was found by which Trichet would attend a meeting of the Institute for International and European Affairs, give an address on the new governance structures of the Eurozone and respond to questions in a semi-structured fashion in a neutral venue in Dublin and while not under oath. This was constitutionally correct for the ECB and the European institutions. It was politically problematic for the local environment. Having created independent central banks in the 
time of crisis they acted independently. In all cases this was in interest of the greater good in the face of confusion, inaction and political paralysis. In most cases this was costly. As was made clear at a recent conference on the legal challenges facing financial stability in the post crisis world at the Bank of England, the reality is that the public purse will be on the line if you do or don't save financial institutions, it is just a matter of when and how chaotic the situation becomes. The political cost will be sufficiently high that it will always be a Pyrrhic Victory for the sitting government.

While that may be considered collateral damage to an economist or technocrat as part of the process of 'good government' or ensuring that central banking does not become a crude instrument of the political business cycle, it does not mean that the political system will not look to intervene. It is clear that the position of the national and supranational central bank, something which makes up a large part of the Banking Inquiry's questioning, is under examination. In the US the Federal Reserve has become quite a political lightning rod (Golub et al. [2015]; Swagel [2015]). The response has been a clear questioning of the role of the lender of last resort. Who has the power to deploy it, who has the access to it and what countermeasures are meant to accompany it at point of request? The unfortunate conclusion so far has been that the Lombard Street understanding of the lender of last resort has an unusual complication, the ability to maintain a structure that is a lender of last resort relies upon it never being actioned. The act of defending the financial system was reputationally suicidal, for to use it will violate the uneasy arrangement between the political classes and the technocrats. While this has seen swift rebuke in the form of the US legislative environment it is only forming into a policy position in Europe as the new Banking Union structures work their way into national laws.

The challenge is that while this is taking place, reviews, such as the Banking Inquiry have no input and national parliaments have limited scrutiny over the implementation of the new laws. That does not mean that the Financial Trilemma of Financial Stability, International Banking, and National Financial Policies has disappeared. It has migrated to a more pliable space, in the public discourse, within the organisations themselves and in the courts. The role of the German Constitutional Court in Karlsruhe has been considered of the utmost importance to the evolution of the economic constitution of Europe. The Irish case brought by Thomas Pringle (Thomas Pringle vs. Government of Ireland the Attorney General C-370/12) before the court of First Instance was one of the rare instances where a European national, in this case a sitting member of parliament, questioned the speed and direction of travel of the undebated economic constitution of Europe. The outline of the economic constitution of the European Union and the Eurozone by Advocate General Kokott was the first statement of the new framework constructed through the Brownian motion of crisis meetings in Brussels. Importantly, except for the high officials and the highest ministers of cabinet, all this had been presented as a fait accompli to parliaments of Europe.

Patience with crisis management and financial reform has worn thin as a result of this approach to policy-making since the crisis. All the while cultures have not changed and 
the dangerous feedback loops that made a financial crisis into an economic and political disaster still remain largely in place. Though the principle objective was to split the banking systems from the sovereign that situation has proved almost impossible, especially in the case of small countries and in an environment where debates over 'secular stagnation' and 'debt super cycles' only work to highlight one profound problem, painfully slow economic growth (Borio [2017]; Rogoff [2016]; Rogoff [2017]). In all circumstances the promises made by past governments and the ability to repay debts will be compromised if growth does not improve.

\section{What can we learn from past errors?}

Ireland has already looked extensively at the crisis, much of the work on what happened between 2008 and 2010 was completed by mid-2011. It provides the background primer on the canvas. As stated above, the Banking Inquiry will look to find the 'smoking gun' in the crisis. The problem is that there exist so many that the process would fall in on itself under its own weight. Something that is already alluded to in the Expert Panel report that it would take 336 hours to conduct the hearings required for the purposes of the terms of reference as original discussed. It is important to note that this was before the addition of the 'role of the media' was added to the terms of reference of the Committee. That is 42 solid days of work, or 14 weeks of meetings according to the schedule of the Irish parliament. Though that may not sound long to some, to the many TDs and Senators that are pursuing seats in the Dail it is a very long time away from canvassing and for party members, this work will have to be secondary to their obligations to their parties, be it on doorsteps or in votes in the upper and lower chambers. Some 38,000 pages of documentation has been submitted to the Inquiry since June of 2014, all of which has to be legally vetted by the civil service secretariat attached to the parliament and marshalled by a committee of investigators specially commissioned by the Inquiry. All of this background work ignores the fact that there has been substantial amounts of effort by official civil service investigations. At present, 752 pages of Irish analysis on the banking crisis have been published. This is not to take into account the analysis performed by academics, the ECB, the IMF or the European Commission. To this effect, we need to ask ourselves to what extent we wish to build on the work of:

1. Report on the crisis in the domestic banking sector: A preliminary analysis and a framework for a banking inquiry. July 2012; Committee of Public Accounts - Irish Parliamentary committee attached to the Office of the Comptroller Auditor General of Ireland ${ }^{1}$

\footnotetext{
${ }^{1}$ Report of the Joint Committee of Inquiry into the Banking Crisis, Chapter 1, Banks, Available at: https://inquiries.oireachtas.ie/banking/volume-1-report/chapter-1/
} 
2. Misjudging Risk: Causes of the Systemic Banking Crisis in Ireland. Report of the Commission of Investigation into the Banking Sector in Ireland. March 2011; Peter Nyberg - Commissioned by the Department of Taoiseach ${ }^{2}$

3. Strengthening the Capacity of the Department of Finance: Report of the Independent Review Panel. December 2010; Rob Wright - Commissioned by the Department of Finance $^{3}$

4. A Preliminary Report on The Sources of Ireland's Banking Crisis. 31 May 2010; Max Watson \& Klaus Regling - Commissioned by the Department of Finance Department of Taoiseach ${ }^{4}$

5. The Irish Banking Crisis: Regulatory and Financial Stability Policy 2003-2008. 31 May 2010; Patrick Honohan - Commissioned by and drafted the Governor of the Central Bank of Ireland ${ }^{5}$

Some of the conclusions drawn by this preliminary work should be the starting point for any further discussion about what happen to Ireland's banking sector and the overall economy. First lets address some of the most salient points for investigation by the Committee: the European dimension, the role of the Central Bank of Ireland, the role of the professions and the contribution of the media.

\subsection{The Central Bank of Ireland}

The Central Bank's role in the banking crisis includes strong opposition to the McDowell proposals [Report of the Implementation Advisory Group on the Establishment of a Single Regulatory Authority for the Financial Services Sector (1999)] for a separate regulatory authority for banks and financial institutions in 1999; failure to regulate in the following decade and the recent belated regulation of loan to value and loan to borrower income some two and a half years after a Seanad private member's bill to introduce such limits. These limits were reviewed in Regling and Watson [2010]. Honohan found that 'there appears to have been little serious thought given to the idea of setting binding or even nonbinding limitations on credit extended specifically to the property sectors'. Nyberg [2011] estimates that such limits by the Financial Regulator would 'if implemented have reduced Irish banks' exposure to the property market by some $€ 62 \mathrm{bn}$ on risk-weighted asset terms.' The Central Bank on June 24, 1999, condemned McDowell as 'deeply flawed' with risks including 'loss

\footnotetext{
${ }^{2}$ Misjudging risk: Causes of the systematic banking crisis in Ireland, Report of the Commission of Investigation into the Banking Crisis in Ireland, March 2011, Available at: http://www.bankinginquiry.gov.ie/Documents/Misjuding220Ireland.pdf

${ }^{3}$ Available at: https://www.per.gov.ie/wp-content/uploads/Review-of-the-Dept-of-Finance.pdf

${ }^{4}$ A review of the Seanad debate is available at: https://www.oireachtas.ie/en/debates/debate/seanad/2013$06-20 / 8$

${ }^{5}$ The Irish Banking Crisis Regulatory and Financial Stability Policy 2003-2008, A Report to the Minister for Finance by the Governor of the Central Bank, Available at: http://www.bankinginquiry.gov.ie/the202003-2008.pdf
} 
of regulatory expertise, difficulty in establishing an international reputation; duplication of supervisory effort, as under the Maastricht Treaty, the Bank must continue to monitor the stability of the banking system and act as lender of last resort; loss of important interaction and transfer of expertise between the bank's regulatory and non-regulatory functions; and high start-up and operating costs.' The Bank's condemnations of the separate regulatory authority is a remarkable forecast of its own conduct leading to the bailout.

Honohan et al. [2010] shows supervisory resources at three teams with three persons each responsible for a) Bank of Ireland and Anglo Irish Bank, (b) eight credit institutions and a branch including INBS and EBS and (c) nine credit institutions and two branches including Ulster Bank. In addition a two person team was responsible for AIB and Irish Life and Permanent. There was also a four person team that conducted prudential inspections across several institutions. The Central Bank was reported in 2012 to have 1500 staff. In addition Nyberg [2011] states that 'it is not clear to the Commission why cooperation from foreign Regulators could not have been sought to help discourage imprudent behaviour in Irish financial markets.' Weak regulation in Ireland of foreign banks coincided with heavy losses for Depfa and Saxony Landbank thus reducing German goodwill towards Irish bank regulation. He also notes that the Financial Stability Report was in theory a cooperative effort by the Central Bank and the Financial Regulator but, in practice, it was almost entirely written by Central Bank staff. Prof Alan Ahearne special advisor to the Minister for Finance during the crisis years, writes that 'an additional dimension to Ireland's crisis was the country's membership of a poorly constructed - and at times dysfunctional - currency union' (Ahearne [2012]). The Irish decision to join the euro despite misgivings expressed by the United Kingdom, Sweden and Denmark is important. The clear absence of a banking union in the past has had profound negative implications for Ireland. This cuts at the most painful question for Ireland and all small countries. Is Ireland an independent nation or is it really a glorified administrative region of the European Union? Having exchanged an explicit colonial master for a more polite interlocutor who comes with CAP money and Structural Funds, engages citizens and senior figures in minor policy discussions but obligates that Ireland must bargain with and hide behind in equal measure the larger

countries of Europe. The Inquiry has great difficulty addressing this deeper existential question for Ireland. It is part of the reason why public support has been muted and many participants have used it as a confessional. When we reflect on this most painful question, how much was any Irishman or Irishwoman in charge of the destiny of Ireland? Better to blame Fortuna and Europa and move on.

\subsection{The Professions}

The conduct of auditors of Irish financial institutions has been questioned in the various early reports. Honohan states 'It may also be the case that auditors and accountants should have been more alert to the banks' lending and financial position' (Honohan et al. [2010]; Nyberg [2011]) 'These were problems of credit quality, sustainable lending practices and adequacy of internal procedures....Auditors, therefore did not feel that commenting on the 
implications of such business model problems fell within their proper remit.'; while 'Support from governments prevented bank collapses in Ireland and elsewhere; it also avoided the legal challenges commonly mounted by liquidators against auditors when businesses collapse soon after clean audit reports' (Nyberg [2011]). Prior to the Guarantee, all of the covered banks received unqualified audit reports on their financial statements. Subsequent to the Guarantee, all of the covered banks continued to receive unqualified audit reports, as did Anglo's September 2008 financial statements. In the majority of cases the auditors did not report regulatory sector lending limit excesses to the Financial Regulator (Nyberg [2011]).

Economists became less involved with the direction of banking in Ireland. Partly this reflected an academic trend, best articulated as 'locally relevant, globally irrelevant' which orientated younger academics away from local economic analysis. The banking sector, as a body, did not seek to engage with economists intellectually. The close links between the Irish banks and the academic community weakened considerably in the lead in to the crisis. The generation of university economists who served on the boards of banks such as Louden Ryan, James Meenan and Patrick Lynch was not replaced in the following generations. The Irish Banking Review, founded in 1957, achieved an international accreditation in the Journal of Economic Literature was suspended by the Irish Banking Federation in 2005. A further reduction in independent analysis of the Irish economy came with the cessation of the publication in the ESRI Quarterly Economic Commentary of policy papers by nonmembers of the Institute staff. Economists within the Irish banks distanced themselves from the wider economics community and became promoters of the property price boom.

The economics profession, despite a period of relative strength during the time of T.K. Whittaker as Secretary General of the Department of Finance during the 1950s, 60s and 70s, was effectively absent from the modern Department of Finance. The Wright Report (2010) reported $^{6}$ that in the Department of Finance's cadre of 542 staff 'only 39 were economists trained to masters-level or higher.' Thirty-nine economists in the Department of Finance is extraordinarily low by international standards. This represented less than $10 \%$ of the total staff compliment at the core of the Department of Finance. In contrast, $60 \%$ of the Canadian Department of Finance are economists trained to masters-level or higher; and about $40 \%$ of staff in the core areas of the Dutch Ministry for Finance are trained to masters-level or higher. While this has changed with the creation of the 'Chief Economist' post in the Department of Finance and the 'Irish Government Economic and Evaluation Service' in the Department of Public Expenditure and Reform, the absence of staff trained in these activities over the duration of the crisis shows a deep lack of analysis in public policy-making. As in most booms, the public and parliament did not question this arrangement as long as days of wine and roses continued unabated.

\footnotetext{
${ }^{6}$ Strengthening the capacity of the Department of Finance, Report of the independent review panel, December 2010, Available at: https://www.per.gov.ie/wp-content/uploads/Review-of-the-Dept-ofFinance.pdf
} 
Journalism also became embroiled in and embattled by the bank-property-state nexus. While some media outlets became dependent upon the bubble for advertising revenues, some were financially compromised by investing in the property bubble after the peak. Some journalists were lone voices of dissent and were subject to public chastisement by none less than the Taoiseach of the day. Journalism had a profound impact on the evaluation of the Irish economy and its banking sector after the 2008 Guarantee. Some journalists (and parliamentarians) did Trojan work attempting to investigate what happened with Anglo Irish Bank. International journalists located in the financial press worked both to identify the departure of the rats as the economy sank, the arrival of the coast guard and the eventual stabilisation and flotation of the Irish economy. The drama and double-speak with the prime minister denying an official sector bailout and then a phone call to the national broadcaster at $08 \mathrm{~h} 13$ on the 18 of November 2010 announcing that Ireland was going to enter a bailout. The departure at $08 \mathrm{~h} 45$ form the Merrion Hotel, across from Department of Finance, for a day of meetings at the Central Bank of Ireland was witnessed by press photographers and the arrival of the Troika was only clarified by clear declarations by the international media that the 'Bailout Boys' were in Dublin.

\section{Concluding Comments}

The bank-property-state nexus that has been provided as the framework of analysis enables the committee members to constantly reference back to the overarching problem: regulatory capture. The inability of the agencies and agents of the State to safeguard the economy from destruction in the name of protecting interest groups, incompetence, shortterm gain and geopolitical expediency has wrought a high price. The previous analysis provides us with a guide. We have somewhere to begin and know the questions to ask. Parliamentary scrutiny and oversight also involves a certain level of introspection. The political system has to be willing to hear the responses, even if they identify serious flaws in how parliament or parliamentarians behaved in the run-up and during the crisis. This will be the beginning of forming solutions. The civil and public service and the wider polity will have to accept the solutions. It is said that you cannot legislate morality but can you legislate to change the political economy? Can the Irish parliament change Irish culture and how it looks at the bank-property-state nexus? Since 2011, very little has changed in the Irish political economy as the permanent government remains firmly in power. The banking sector, now wrapped in a friendly de facto duopoly model will also have to reform and become useful for the economy of Ireland to just survive. Overall, the political system has witnessed the effect of economic failure.

What of the future? The failure of parliamentary inquiries is that we are backwardlooking with an aim of creating future policy. This was the failure of all such exercises, even the wildly successful Pecora Commission. It did not see that cultures would change and 'paradigm shifts' would render the simple legislation it acted as midwife for being set aside with speed and ease. Will the crises facing Ireland be the same as in 2008? Most likely 
not. Will the new Banking Union prevent 2008? It may prevent 2008 but not what will happen in 2038 or when the next financial crisis. A lesson learned swiftly in public office is the dangers of hubris. It is something economists and technocrats rarely realise but there are clear limits to the effectiveness of the social planner and the optimal policy. There is wisdom and madness in equal measure in crowds, and the only thing that will continue to surprise you about your polity and its citizens is its ability to surprise you. While present in Colonia Iulia Aemona at the edge of the Roman province of Italia one should note that there is a possibility that the European bodies that consolidated the position of the crisis and at times provided leadership should not fall prey to the hubris of Coriolanus when facing the collective peoples of Europe and repudiate them.

As policymakers, technocrats and thinkers we here must remember that the world elsewhere sits not in the limited frameworks designed to make matters manageable but exists on a grander scale and we must pay due attention to the transaction costs of constitutional democracy. It is coin well spent.

\section{References}

Ahearne, A. (2012). Political-economic context in ireland. Resolving the European Debt Crisis 21, 37.

Barrett, G. (2018). European economic governance: deficient in democratic legitimacy? Journal of European Integration 40(3), 249-264.

Becker, B. and V. Ivashina (2017). Financial repression in the european sovereign debt crisis. Review of Finance 22(1), 83-115.

Black, L., R. Correa, X. Huang, and H. Zhou (2016). The systemic risk of european banks during the financial and sovereign debt crises. Journal of Banking 85 Finance 63, 107-125.

Borio, C. (2017). Secular stagnation or financial cycle drag? Business Economics 52(2), $87-98$.

Coleman, N., A. Georgosouli, and T. Rice (2018). Measuring the implementation of the fsb key attributes of effective resolution regimes for financial institutions in the european union. FRB International Finance Discussion Paper (1238).

Connor, G., T. Flavin, and B. O'Kelly (2012). The us and irish credit crises: Their distinctive differences and common features. Journal of International Money and Finance 31(1), $60-79$.

Cooper, R. and K. Nikolov (2018). Government debt and banking fragility: The spreading of strategic uncertainty. International Economic Review 59(4), 1905-1925. 
Corbet, S. (2016). Turning tigers into PIIGS: The role of leverage in the irish economic collapse. In Lessons from the Great Recession: At the Crossroads of Sustainability and Recovery, pp. 21-55. Emerald Group Publishing Limited.

Corbet, S. and C. Larkin (2017). Has the uniformity of banking regulation within the european union restricted rather than encouraged sectoral development? International Review of Financial Analysis 53, 48-65.

Corbet, S. and C. Larkin (2018). Populism and extremism: The immediate political challenges to europeanism. Geoforum.

Corbet, S. and C. Twomey (2014). How have contracts for difference affected irish equity market volatility? The Economic and Social Review 45(4, Winter), 559-577.

De Marco, F. (2019). Bank lending and the european sovereign debt crisis. Journal of Financial and Quantitative Analysis 54(1), 155-182.

Donovan, D. and A. E. Murphy (2013). The fall of the Celtic tiger: Ireland and the euro debt crisis. Oxford University Press.

Golub, S., A. Kaya, and M. Reay (2015). What were they thinking? the federal reserve in the run-up to the 2008 financial crisis. Review of International Political Economy 22(4), $657-692$.

Hick, R. (2018). Enter the troika: The politics of social security during ireland's bailout. Journal of Social Policy 47(1), 1-20.

Honohan, P. (2009). What went wrong in ireland. Prepared for the World Bank.

Honohan, P. (2010). Euro membership and bank stability-friends or foes? lessons from ireland. Comparative Economic Studies 52(2), 133-157.

Honohan, P., D. Donovan, P. Gorecki, and R. Mottiar (2010). The irish banking crisis: Regulatory and financial stability policy.

Kinsella, S. (2012). Is ireland really the role model for austerity? Cambridge Journal of Economics 36(1), 223-235.

Kirby, P. (2016). The Celtic tiger in distress: Growth with inequality in Ireland. Springer.

Lucey, B. M., C. Larkin, and C. Gurdgiev (2014). Learning from the irish experience-a clinical case study in banking failure. Comparative Economic Studies 56(2), 295-312.

Nugent, N. (2017). The government and politics of the European Union. Palgrave.

Nyberg, P. (2011). Misjudging risk: Causes of the systemic banking crisis in ireland. Report of the Commission of Investigation into the Banking Sector in Ireland. 
Regling, K. and M. Watson (2010). A preliminary report on the sources of Ireland's banking crisis. Government Publications Office Dublin, $\mathrm{OH}$.

Rogoff, K. (2016). Debt supercycle, not secular stagnation. Progress and confusion: the state of macroeconomic policy, 19.

Rogoff, K. (2017). Dealing with monetary paralysis at the zero bound. Journal of Economic Perspectives 31(3), 47-66.

Swagel, P. (2015). Legal, political, and institutional constraints on the financial crisis policy response. Journal of Economic Perspectives 29(2), 107-22.

Tesche, T. (2018). Instrumentalizing emuâĂŹs democratic deficit: the ecbâĂŹs unconventional accountability measures during the eurozone crisis. Journal of European integration, 1-17.

Whelan, K. (2014). Ireland's economic crisis: The good, the bad and the ugly. Journal of Macroeconomics 39, 424-440. 
Figure 1: Committee of Inquiry in the Irish Banking Crisis

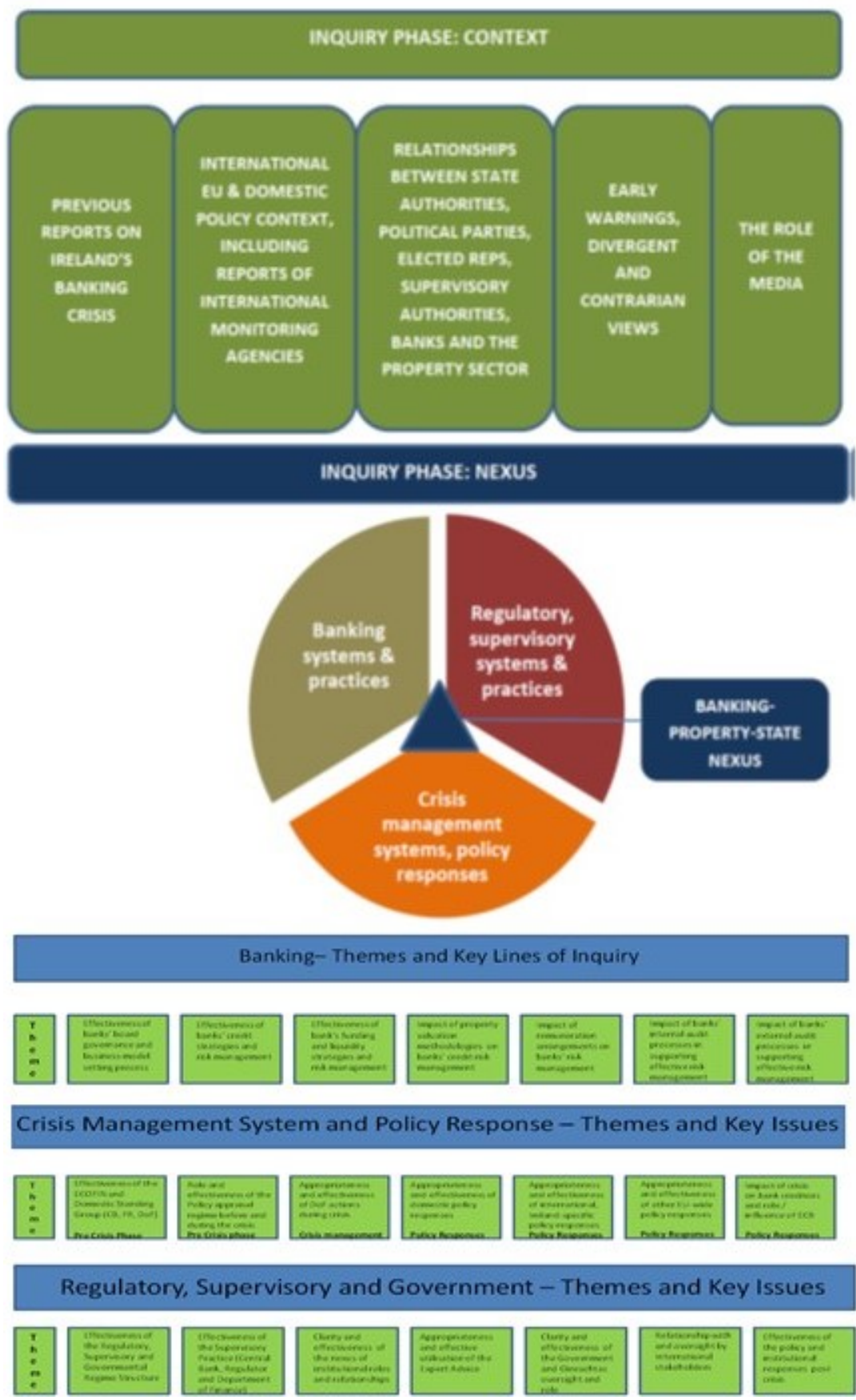

Source: Top Section, Relevant Proposal to the Committee on Procedure and Privileges of Dail Eireann and Seanad Eireann. 29 September 2014, page 19. Bottom Section, Banking Inquiry Secretariat. January 2015. 